\title{
Celebrity Worship pada Dewasa Awal Penggemar K-Pop di Palembang
}

\author{
Indah Lestari $^{\mathrm{a} *}{ }^{*}$ Zaharuddin $^{\mathrm{b}}$, and Sarah Afifah ${ }^{\mathrm{c}}$ \\ ${ }^{a, b, c}$ Universitas Islam Negeri Raden Fatah Palembang \\ *Corresponding author: Lestariindah094@gmail.com
}

\begin{abstract}
Abstrak
Penelitian ini bertujuan untuk menggambarkan celebrity worship pada dewasa awal penggemar K-pop di Palembang. Metode yang digunakan pada penelitian ini adalah metode penelitian kualitatif dengan rancangan deskriptif. Subjek dalam penelitian ini berjumlah 3 orang perempuan yang merupakan seorang dewasa awal dengan menggunakan purposive sampling. Selanjutnya metode pengumpulan data menggunakan wawancaraa, observasi, dan dokumentasi. Sedangkan analisis data menggunakan pengumpulan data, reduksi data, display data, dan kesimpulan/verifikasi. Hasil penelitian ini menunjukkan gambaran celebrity worship ketiga subjek yang menampilkan perilaku obsesi kecintaan terhadap dan pemujaan irasional terhadap idola k-pop yang disukai. Selanjutnya, faktor-faktor yang mempengaruhi ketiga subjek melakukan celebrity worship yaitu faktor dari dalam diri dan faktor dari luar diri.
\end{abstract}

\section{Kata Kunci}

Celebrity worship; Dewasa Awal; Penggemar k-pop

\begin{abstract}
This study aims to describe Celebrity Worship in Early Adult K-pop Fans in Palembang. The method used in this research is a qualitative research method with a descriptive design. Subjects in this study were 3 women who were early adults using purposive sampling. Furthermore, the data collection method uses interviews, observation, and documentation. Meanwhile, data analysis uses data collection, data reduction, data display, and conclusion / verification. The results of this study show a description of the three subjects' Celebrity Worship that displays the behavior of obsession with love for and irrational worship of the preferred $k$-pop idols. Furthermore, the factors that influence the three subjects to do Celebrity Worship are internal factors and external factors.
\end{abstract}

\section{Keywords}

Celebrity Worship; Early Adult; K-pop Fans 


\section{Pendahuluan}

emajuan dari sisi kehidupan
manusia
kehidupan kehidupan sosial budaya, serta kehidupan dalam aspek teknologi telah memudahkan dalam mendapatkan informasi di berbagai Negara. Informasi yang dapat diperoleh berupa kecantikan, kesehatan, pendidikan, serta hiburan. Hiburan dapat berkaitan dengan K-pop adalah salah satu hiburan yang berasal dari negara Korea Selatan. Kpop adalah kepanjangan dari Korean Pop (Musik Pop Korea). Popularitas K-pop semakin berkembang dibeberapa negara termasuk di Indonesia.

Penggemar K-pop di dunia hampir tembus 90 juta orang. $\mathrm{CN}$ Indonesia mencatat ada 1.843 klub penggemar di 113 negara di dunia. Totalnya adalah 89,19 juta. Angka itu naik sekitar 22 persen dari 2017 (www.cnindonesia.com). Fenomena budaya Korea di Indonesia berkembang sejak tahun 2000-an dimulai dengan tayangan drama Korea di televisi Indonesia dan juga membuka k-pop masuk ke Indonesia (www.m.detik.com). Popular kpop di Indonesia terjadi di berbagai kota yang ada di Indonesia, salah satunya di kota Palembang.

Penggemar K-pop di Palembang cukup banyak, dibuktikan dengan banyaknya komunitas yang ada di Palembang. Terlihat pada salah satu kegiatan yang diadakan oleh komunitas UKLI (United Kpop Lovers Indonesia) di Palembang yang perkiraan jumlah orang yang datang adalah 1000 orang, tapi yang datang sampai 3000 orang (www.tribunsumsel.com).
Idola k-pop yang paling disukai disebut bias. Bias merupakan singkatan dari Being Inspired and Addicted to Someone (www.kapanlagi.com). Bias (idola k-pop yang paling disukai) seorang penggemar bisa lebih dari satu. Ultimate bias (idola kpop yang paling disukai) adalah raja atau ratu dari daftar bias (idola k-pop yang paling disukai) atau bias (idola k-pop yang paling disukai) utama. Komunitas di Palembang merupakan komunitas aktif terlihat di akun sosial media yang selalu ada kegiatan pada saat hari-hari tertentu contohnya pada saat kegiatan perayaan hari ulang tahun bias (idola k-pop yang paling disukai), event album baru, dan hari-hari perayaan penting yang berhubungan tentang bias (idola k-pop yang paling disukai).

Penggemar menunjukan dukungan kepada bias secara langsung dan tidak langsung. Dukungan secara tidak langsung dilakukan dengan cara membeli barang-barang yang berhubungan dengan bias, menghadiri kegiatan yang berhubungan dengan bias, sedangkan secara langsung salah satunya dengan cara membeli tiket konser (www.Kapanlagi.com).

Kecintaan terhadap bias mampu menimbulkan berbagai macam perilaku, salah satunya adalah perilaku imitasi. Perilaku imitasi yang dilakukan terhadap perilaku bias dapat menyebabkan penggemar terobsesi yang menyebakan hubungan satu arah antara penggemar dan Idola k-pop yang paling disukai (McCutcheon, Ashe, Houran, \& Maltby, 2003). Kencintaan terhadap bias (Idola kpop yang paling disukai) dapat menyebabkan perilaku menyimpang pengemar k-pop. Hal ini sesuai dengan penelitian Maltby, Day, dan Liza (2011), 
bahwa salah satu faktor dalam pemilihan kosmetik adalah kebiasaan celebrity worship pada seseorang, serta menunjukan adanya jenis hubungan para-sosial dewasa muda dengan selebriti, terutama dengan mereka yang bentuk tubuh dikaguminya, serta mungkin perlu dipertimbangkan pada saat pemilihan kosmetik.

Celebrity worship dapat terjadi pada siapa saja. Menurut McCutcheon, dkk (2004) menyatakan terdapat tiga aspek celebrity worship yaitu entertainment-social, intense-personal, dan borderlinepathological. Entertainment-social adalah kecintaan terhadap kemampuan selebriti dalam menghibur, intense-personal adalah perasaan intensif dan kompulsif terhadap selebriti, sedangkan borderlinepathological berkaitan dengan kecenderungan perilaku yang patologis akibat pemujaan yang berlebihan.

Penggemar idola k-pop biasanya terjadi pada tahap perkembangan remaja. Remaja yang sedang mencari jati diri akan mencari atau mengikuti beberapa model yang menurutnya terbaik dalam menjalani kehidupannya, cara berpakaian, make up, dan cara bicara yang digunakan sehari-hari. Banyak remaja yang menjadikan idola sebagai model atau panutan dalam bertingkah laku.

Hal ini sejalan dengan hasil penelitian yang dilakukan oleh Sunarni, (2016) yang menyatakan $71,95 \%$ remaja SMA di Yogyakarta sebagian besar memiliki proses identitas diri model informasi. Kemudian penelitian Fredika, dkk (2015), Hasil dari penelitian menunjukkan bahwa ada hubungan positif antara harga diri dan celebrity worship pada remaja di SMP Negeri 43 Surabaya.
Masa remaja adalah perubahan tahap perkembangan dari masa anak-anak ke masa dewasa. Setiap masa perkembangan mempunyai tugas serta ciri-ciri yang berbeda. Pada masa dewasa awal salah satu tugas perkembangan pada tahap perkembangan ini menurut Erik $\mathrm{H}$ Erikson (dalam Alwisol, 2009) adalah untuk menjalin hubungan intim berkaitan dengan krisis intimacy vs isolation, masa dewasa awal untuk membentuk interpersonal relationship yang mendalam dengan lawan jenis atau biasa disebut dengan intimate relationship.

Penelitian oleh Darfiyanti dan Putra (2012), menyatakan keterkaitan antara pemujaan terhadap idola pop dengan intimate relationship terletak pada kriteria pasangan ideal dan prioritas hubungan pada saat ini. Penelitian lain yang mendukung dilakukan oleh McCutcheona, dkk (2016), menyatakan bahwa salah satu faktor intimate relationship yang buruk adalah pengidolaan terhadap selebriti.

Berdasarkan studi pendahuluan yang telah peneliti lakukan tentang bagaimana perilaku kecintaan. NB adalah seorang mahasiswa aktif di salah satu universitas negeri di Palembang, berusia 23 tahun. subjek menyukai K-pop sejak tahun 2011, dijelaskan bahwa awalnya subjek senang karena sering mendengar lagu-lagu serta tahu dari teman yang juga senang K-pop. Bias (Idola k-pop yang paling disukai) yang ia miliki lebih dari satu, mempunyai ultimate bias. NB sangat mengetahui tentang biasnya terlihat saat ia menceritakan bias.

RA adalah seorang mahasiswa aktif di salah satu universitas Swasta di Palembang, berusia 22 tahun. Ia menyukai K-pop sejak 
tahun 2009, dijelaskan bahwa awalnya ia senang karena sering menonton $\mathrm{mv}$ dari Super Junior serta tahu dari teman yang juga senang K-pop. Bias (idola k-pop yang paling disukai) yang subjek miliki lebih dari satu, mempunyai ultimate bias. Dijelaskan bahwa RA mempunyai banyak barang yang berhubungan dengan bias (Idola k-pop yang paling disukai). Mereka menjalani kehidupan seperti biasanya. Melakukan aktivitas kuliah, berinteraksi dengan keluarga, teman sebaya, maupun lingkungan yang lebih luas.

ND dan RA selalu meluangkan waktu untuk melihat perkembangan dari biasnya. Biasanya mereka tergabung melalui whatsApp, line, telegram, serta mengikuti akun sosial media instagram, twitter, youtube.

Kondisi Indonesia saat ini tengah mengalami wabah yang sangat berbahaya. Wabah ini terjadi secara menyeluruh didunia. Wabah ini dikenal dengan Pandemi Covid-19 atau Virus Corona Disease (covid-19). Dalam kondisi pandemi akibat virus disease (Covid-19) menimbulkan beberapa aktivitas masyarakat menjadi terhambat karena melakukan isolasi dari dunia luar. Tidak hanya menimbulkan dampak bagi kesehatan masyarakat dan keselamatan masyarakat, covid-19 juga memberikan dampak terhadap perkembangan dan aktivitas-aktvitas penggemar k-pop.

Dampak pandemik covid-19 menyebabkan mendorong peningkatan penjualan album. Pandemi covid-19 menyebabkan sebagian besar aktivitas para boyband dan girlband Korea tertunda, terutama acara seperti konser dan fan meeting baik di Korea maupun dunia. Berdasarkan data Gaon Chart, penjualan album fisik K-pop di dalam dan luar negeri diperkirakan bisa mencapai 35 juta keping hingga akhir 2020. Angka tersebut melonjak dibandingkan data penjualan pada 2019, yakni 25 juta keping album Kpop (www.cnindonesia.com). Hal ini sesuai dengan hasil wawancara yang dilakukan peneliti dengan subjek.

Dari hasil wawancara dan observasi yang dilakukan, maka dapat di ketahui bahwa memang benar subjek yang sudah memasuki tahap dewasa awal yang melakukan kencintaan terhadap selebriti. Masa dewasa terbagi menjadi tiga yaitu masa dewasa awal, masa dewasa tengah, dan masa dewasa akhir.

Menurut Papalia, Old, dan Feldman (2008), masa dewasa awal (young adulthood) berkisar antara usia 20 sampai dengan 40 tahun. Subjek yang sudah memasuki usia dewasa awal yang idealnya sebagaimana menurut R.J. Havighurst (dalam Hurlock, 1980) menyatakan seharusnya tugas perkembangan dewasa awal adalah mulai bekerja, memilih pasangan, belajar hidup dengan tunangan, mulai membina keluarga, mengasuh anak, mengelolah rumah tangga, mulai bertanggung jawab terhadap Negara sebagai warga Negara, mencari kelompok sosial yang menyenangkan, tetapi kenyatanya masih melakukan pemujaan terhadap selebriti berdasarkan hal ini menarik untuk di kaji. Berdasarkan uraian masalah diatas peneliti meneliti lebih lanjut mengenai celebrity worship pada dewasa awal pengemar K-pop di Palembang.

\section{Metode}

Jenis penelitian yang digunakan kualitatif, dengan metode deskriptif. Metode penelitian kualitatif, menurut Creswell 
(dalam Raco, 2010) adalah pendekatan atau penelusuran untuk mengetahui, mengeksplorasi dan memahami suatu gejala-gejala sentral. Artinya dalam penelitian kualitatif tema yang akan dipilih adalah hal-hal yang sedang terjadi di lingkungan atau fenomena yang penting untuk di teliti, melakukan pemahaman serta penelusuran pada gejala-gejala yang sedang terjadi.

Azwar (2016), mengatakan penelitian kualitatif lebih menekankan analisinya pada proses penyimpulan deduktif dan induktif serta pada analisis terhadap dinamika hubungan antar fenomena yang diamati dengan menggunakan logika ilmiah. Pada penelitian kualitatif ini melakukan penelitian dengan menggunakan fenomena yang terjadi, melakukan pengumpulan data, data dianalis, serta dilakukannya keabsahan data.

Peneliti menggunakan jenis penelitian ini karena sesuai dengan tujuan penelitian, yaitu untuk memahami dan memaknai celebrity worship subjek. Hal ini karena menurut Herdiansyah (2015), mengatakan dalam rana ilmu psikologi tujuan penelitian kualitatif difokuskan pada penggalian makna dan nilai (values) dari pengalaman-pengalaman subjek penelitian dimana makna atau nilai tersebut menjadi dasar dalam bersikap dan berperilaku dalam batasan central phenomenon yang diteliti. Denzin dan Yvonna S. penelitian kualitatif melibatkan studi menggunakan dan mengkoleksi variasi materi-materi empiris, studi kasus, pengalaman personal, introspektif, life histori, interview, observasi, sejarah, interaksional, dan teks visual yang mengambarkan rutinitas dan problem waktu dan arti hidup individual (dalam Pradoko, 2017).

Berdasarkan penjelasan diatas maka Metodologi ini dapat dipahami sebagai prosedur penelitian yang menghasilkan data deskriptif berupa kata-kata tertulis atau lisan dari orang, yang difokuskan pada penggalian makna dan nilai dalam bersikap dan berperilaku dari subjek penelitian. Alasan peneliti menggunakan metode penelitian kualitatif deskriptif dikarenakan peneliti ingin memahami proses mengenai tema yang akan diteliti secara mendalam.

Adapun karakteristik subjek dalam penelitian ini yaitu:

a. Dewasa awal dengan rentang usia 18-25 tahun.

b. Dewasa awal yang telah memiliki barang-barang idola k-pop.

c. Dewasa awal yang telah menjadi penggemar idola k-pop minimal 4 tahun.

d. Dewasa awal penggemar k-Pop di Palembang.

e. Bersedia untuk menjadi subjek dalam penelitian.

\section{Observasi}

Gordon E. Mills (dalam Herdiansyah, 2015) mendefinisikan observasi adalah suatu kegiatan yang terencana dan terfokus untuk melihat dan mencatat berbagai perilaku ataupun jalannya sebuah sistem yang memiliki tujuan tertentu, serta dapat digunakan untuk menyatakan alasan munculnya perilaku dan landasan suatu sistem tertentu.

Jenis observasi yang digunakan dalam penelitian ini adalah observasi tidak berstruktur. Menurut Sugiyono (2016) 
Observasi tidak berstruktur adalah observasi yang tidak dipersiapkan secara sistematis tentang apa yang akan di observasi. Hal ini dilakukan karena peneliti tidak tahu secara pasti tentang apa yang akan diamati. Dalam melakukan pengamatan peneliti tidak menggunakan instrumen yang telah baku, tetapi hanya berupa rambu-rambu pengamatan.

\section{Wawancara}

Stewart dan Cash (dalam Herdiansyah, 2015) mendefinisikan wawancara adalah interaksi yang di dalamnya terjadi pertukaran, tanggung jawab, perasaan, kepercayaan, motif dan informasi. Dalam penelitian ini wawancara dilakukan dengan menggunakan pedoman wawancara semiterstruktur. Menurut Herdiansyah (2015), wawancara semi-terstruktur merupakan wawancara yang relatif aman dan mudah digunakan terutama oleh pemula. Penelitian ini akan menggali data dengan wawancara semi-terstruktur pada subjek penelitian yaitu penggemar K-pop Dewasa Awal di Palembang.

\section{Dokumentasi}

Menurut Sugiono (2016), Dokumentasi merupakan pengumpulan data yang berupa catatan kegiatan-kegiatan yang suda terjadi. Dokumen bisa berbentuk tulisan, gambar atau karya-karya dari seseorang. Dokumen yang berbentuk tulisan bisa dokumen pribadi atau resmi. Data dokumentasi yang akan digunakan adalah berupa hasil foto, rekaman, serta data-data mengenai yakni penggemar K-pop di Palembang.

\section{Metode Analisis Data}

Penelitian ini menggunakan teknik metode analisis data Miles dan huberman (dalam Herdiansyah, 2015) menyatakan tahap- tahap metode analisis data yaitu: 1 . Pengumpulan data. Pada tahap ini proses pengumpulan data awal umunya peneliti melakukan studi pre-eliminary yang sudah termasuk dalam proses pengumpulan data. 2. Reduksi data. Reduksi data adalah proses penggabungan dan penyeragaman segala bentuk data yang diperoleh menjadi satu bentuk tulisan yang akan dianalisis. 3 . Display data. Display data adalah mengolah data setengah jadi yang sudah seragam dalam bentuk tulisan dan sudah memiliki alur tema yang jelas. 4. Verifikasi. Tahap penarikan kesimpulan terdiri dari prosesproses, karena menjurus pada jawaban dari pertanyaan penelitian yang telah diajukan.

\section{Hasil dan Diskusi}

Di dalam pembahasan ini, peneliti akan membangi menjadi tiga episode sebagai berikut:

Penelitian ini membahas tentang Celebrity Worship pada Dewasa Awal Penggemar KPop di Palembang. Dengan 3 orang subjek penelitian yaitu: TS, EW, dan SP. Ketiga subjek merupakan penggemar k-pop di Palembang, ketiga subjek telah menjadi penggemar K-Pop lebih dari 5 tahun.

Berdasarkan hasil temuan penelitian ketiga subjek melakukan kecintaan terhadap idola yang disukai, terlihat dari: Bentuk-bentuk kecintaan subjek terhadap idola k-pop yang disukai, Obsesi kecintaan subjek terhadap idola k-pop yang disukai, Pemujaan irasonal terhadap idola K-pop yang disukai. Akan diuraikan berdasarkan tema-tema yang telah ditemukan di penelitian ini.

Pada tema 1 membahas tentang latar belakang ketiga subjek. Ketiga subjek pada penelitian adalah penggemar idola k-pop 
berinisial, TS (20), EW (20), dan SP (19). Sebagaimana yang diungkap oleh (Santrok, 2018) masa dewasa adalah masa transisi dari masa remaja ke masa dewasan (emerging adulthood) dari umur 18 tahun sampai dengan umur 25 tahun. Pada masa ini individu mulai melakukan perubahan terhadap hidup pola hidup. Sedangkan yang diungkap oleh (Hurlock, 1980) masa dewasa dini dimulai umur 18 tahun sampai dengan umur 40 tahun. Masa dewasa biasanya terbagi menjadi 3 fase perkembangan yaitu masa masa dewasa dini, masa dewasa madya, dan masa dewasa lanjut.

Pada tema 2 Latar belakang menjadi Penggemar K-pop di Palembang. Berdasarkan hasil penelitian yang dilakukan pada ketiga subjek didukung oleh informan, serta dibuktikan dengan dokumentasi sebagai berikut. Berdasarkan hasil penelitian subjek TS sudah 12 tahun, subjek EW sudah 11 tahun dan subjek SP sudah 6 tahun. Subjek TS menjelaskan bahwa subjek menyukai k-pop sejak tahun 2009 karena drama Korea yang diperankan oleh aktris Korea yang ganteng dan cantik. Kemudian subjek TS menyukai beberapa girls band dan boy band Korea dan subjek menyukai SM Stand.

Subjek EW latar belakang subjek menyukai k-pop adalah pada saat subjek kelas 4 SD berusia 10 tahun, karena menonton drama yang ditayangkan di televisi, kemudian subjek EW mulai mencari informasiinformasi untuk mengetahui tentang idola k-pop dan semakin tertarik hingga saat ini. Menurut subjek SP latar belakang subjek menjadi penggemar k-pop adalah pada saat subjek kelas 10 SMA, subjek melihat teman-teman yang menonton k-pop, subjek mulai tertarik dengan idola k-pop kemudian mulai mencari informasi-informasi tentang idola k-pop. Ketiga subjek mulai menyukai idola k-pop sebelum memasuki usia dewasa awal. Subjek TS dan subjek EW mulai menyukai idola k-pop pada rentang usia 910 tahun dimana menurut Hurlock (1980) rentang usia tersebut termasuk ke masa kanak-kanak akhir, sedangkan subjek SP mulai menyukai idola k-pop pada rentang usia 16 tahun dimana menurut Hurlock (1980) rentang usia tersebut memasuki masa kanak-kanak akhir dan masa remaja awal.

Pada tema 3 Alasan dari dalam diri subjek menjadi Penggemar K-pop di Palembang. Berdasarkan penelitian yang dilakukan untuk mengetahui alasan dari dalam diri ketiga subjek menjadi penggemar K-pop di Palembang akan dibahas sebagai berikut. Alasan ketiga subjek menjadi penggemar K-pop di Menurut subjek TS faktor internal subjek menyukai idola k-pop adalah karena penampilan fisik yang dimiliki idola, lagulagu k-pop serta subjek menjelaskan lebih lanjut bahwa subjek menyukai lagu k-pop yang bergenre ngebit karena subjek menyukai menari.

Faktor internal subjek EW menurutnya karena subjek menyukai idola k-pop karena subjek merasa dengan adanya idola k-pop subjek lebih semangat dalam menjalankan aktivitas-aktivitas sehari-hari dan tampilan fisik yang dimiliki oleh idola k-pop, subjek mengatakan bahwa idola k-pop itu sangat ganteng dan sempurna. Menurut subjek SP faktor internal subjek menjadi penggemar k-pop karena melihat tampilan fisik idola yang ganteng dan tinggi, membuat nyaman serta kemampuan. ketiga subjek menyukai idola k-pop karena penampilan dan kemampuan idola, hal sejalan dengan hasill penelitian yang dilakukan oleh Dafriyanti 
dan Putra (2012) mengatakan alasan awal menyukai idola k-pop karena kemampuan dan penampilan dari idola yang disukai.

Pada tema 4 Alasan dari luar diri subjek menjadi Penggemar K-pop di Palembang. Menurut subjek TS perkembangan teknologi dan lingkungan keluarga mempunyai pengaruh selama subjek TS menjadi penggemar k-pop. Perkembangan teknologi sangat berpengaruh terhadap aktivitas-aktivitas selama menjadi penggemar k-pop, contohnya sebelum adanya internet melihat perkembang idola k-pop yang disukai melalui kaset, $\mathrm{CD}$, dan melalui televisi. Setelah adannya internet sangat membantu subjek TS dalam menjalani aktivitas-aktivitas sebagai penggemar k-pop, subjek menggunakan internet untuk streming youtube tentang idola k-pop yang disukai. Menurut subjek EW saat awal-awal menyukai k-pop untuk melihat keseharian idola yang disukai melalui majalah, televisi, radio, dan kasetkaset. Subjek EW harus menabung untuk membeli majalah yang harganya cukup mahal, melalui televisi yang tayangannya di ulang-ulang tidak sesuai dengan apa yang diharapkan oleh subjek, serta melalui radio yang kadang tidak sesuai dengan lagu yang diharapkan.

Subjek EW mengatakan karena perkembangan teknologi membuat lebih mudah untuk mengetahui perkembangan dari idola k-pop yang disukai, misal pada saat ini bisa melalui youtube, serta saat ini sudah banyak festival-festival k-pop. Selain pengaruh dari kecanggihan teknologi, keluarga subjek juga mempunyai pengaruh selama subjek menjadi penggemar k-pop. Sedangkan menurut subjek SP pergaulan teman sebaya sangat berpengaruh terhadap aktivitas-aktivitas subjek selama menjadi penggemar k-pop karena subjek dan teman subjek berbagi segala macam berhubungan dengan idola k-pop yang disukai.

Perkembangan teknologi juga sangat berpengaruh terhadap pengalaman subjek menjadi penggemar k-pop hal ini terlihat dari penggunaan internet yang dilakukan subjek, seperti penggunaan instagram, youtube, dan sosial media lainnya. Berdasarkan hasil penelitian yang dilakukan subjek TS dan EW faktor eksternal yang sangat mempengaruhi subjek menjadi penggemar k-pop adalah perkembangan teknologi dan keluarga, sedangkan subjek SP faktor eksternal yang sangat mempengaruhi subjek menjadi penggemar k-pop adalah perkembangan teknologi dan teman sebaya subjek. ketiga subjek menghabiskan banyak aktivitasaktivitas untuk idola k-pop yang disukai saat menjadi penggemar k-pop dan menjadikan idola k-pop yang disukai sebagai contoh dalam aktivitas-aktivitas yang dilakukan.

Islam menjelaskan contoh atau teladan manusia paling sempurna adalah Nabi Muhammad SAW. Setiap Muslim diperintah Allah SWT untuk meneladani Rasulullah dalam seluruh aspek kehidupan. Firman Allah dalam QS. Al-Ahzab 33:21:

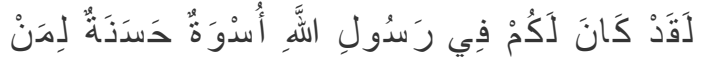

$$
\begin{aligned}
& \text { كَانَ بَرْْ جُج }
\end{aligned}
$$

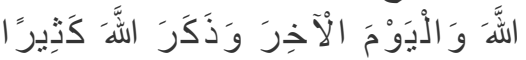

Artinya "Sesungguhnya telah ada pada (diri) Rasulullah itu suri teladan yang baik bagimu (yaitu) bagi orang yang mengharap (rahmat) Allah dan (kedatangan) hari kiamat dan dia banyak menyebut Allah". (QS. Al-Ahzab $33: 21)$. 
Pada tema 5 Bentuk-bentuk kecintaan subjek terhadap idola K-pop saat menjadi Penggemar K-pop di Palembang. Berdasarkan hasil penelitian yang dilakukan untuk mengetahui bentuk-bentuk kecintaan subjek. Menurut subjek TS akan merasa dekat dengan orang yang menyukai k-pop dan subjek merasa bahagia saat mendengar lagu dan poster idola yang disukai ditempat umum. Menurut subjek EW saat bertemu dengan orang baru yang menyukai k-pop maka subjek akan lebih dekat serta memiliki pembahasan dan subjek menjelaskan akan bahagia saat mendengar lagu idola k-pop dan poster kpop yang disukai ditempat umum. Subjek SP menjelaskan bahwa subjek akan mencari informasi tentang idola yang disukai melalui sosial media, subjek akan merasa dekat dengan orang yang menyukai k-pop karena mempunyai topik pembahasan yang tidak membosankan dan subjek menjelaskan bahwa akan merasa bahagia saat mendegar lagu idola yang disukai ditempat umum.

Ketiga subjek mempunyai sikap yang hampir sama dalam melakukan kecintaan subjek terhadap idola K-pop, hal ini sejalan dengan Dayaksini dan Hudaniah, (2015) sikap adalah respon-respon yang diperlajari karena adanya stimulus tertentu. Ketiga subjek mempunyai stimulus yang sama yaitu idola yang disukai. tentang pemujaan berlebihan terhadap idola k-pop yang disukai.

Pada tema 6 Obsesi kecintaan subjek terhadap idola K-pop saat menjadi Penggemar K-pop di Palembang. Berdasarkan hasil penelitian yang dilakukan. Subjek TS memilki barangbarang k-pop berupa poster, foto cart, stiker, pena, binder, dan kalung. Subjek TS mengikuti semua akun sosial media idola yang disukai, seperti youtube, fecebook, instagram dan twitter. Subjek TS mengatakan aktivitas-aktivitas yang dilakukan menonton youtube, variety show, streming dan subjek menyukai lebih dari satu idola k-pop.

Subjek WE memiliki barang-barang k-pop berupa lighstik, album, dan poster, pena, buku, binder dan subjek akan membeli barang-barang k-pop yang ditawarkan kepada subjek. Subjek WE mengatakan pada saat awal-awal menyukai k-pop melihat keseharian idola yang disukai melalui majalah, televisi, radio, kaset-kaset dan untuk saat ini melalui sosial media. Bagi subjek WE mengetahui kegiatan idola yang disukai sudah menjadi kebiasaan dilakukan setiap hari. Kemudian Subjek SP memiliki barang-barang k-pop berupa poster, foto cart, stiker, dan pena. Subjek SP mengikuti akun sosial media dari agensi idola yang disukai dan akun sosial media idola yang disukai, seperti youtube, instagram dan freelive. Subjek SP mengatakan setiap waktu subjek akan mencari waktu yang sesuai dengan keadaan subjek.

Ketiga subjek mempunyai atensi yang hampir sama terhadap idola yang disukai, menurut Baihaqi (2016) mengatakan atensi merupakan konsep yang digunakan individu untuk mengambarkan proses dalam menangkap dunia luar.

Pada tema 7 tentang pemujaan irasional terhadap idola k-pop yang disukai. Menurut subjek TS idola k-pop yang disukai sangat berpengaruh di kehidupan subjek, subjek lebih mengerti dan tau lagu Korea dibandingkan dengan lagu Indonesia, serta subjek mengatakan tidak ada niat untuk 
berhenti menjadi pengemar k-pop. Sikap subjek TS jika ada yang menghina idola kpop yang disukai, subjek akan besikap biasa saja tapi jika memang sudah menyerang maka subjek akan menyerang balik. Serta subjek merasa sedih jika kehilangan idola k-pop yang disukai, gagal tampil di konser dan serta merasa sangat sedih saat mengetahui idola yang disukai sakit.

Subjek EW mengatakan menyukai k-pop tidak mempunyai dampak negatif di kehidupan, malah sebaliknya idola k-pop yang disukai mampu memberikan dampak positif di kehidupan subjek. Subjek EW akan merasa sangat bahagia jika mendengar berita tentang idola yang disukai berkarya kembali. Jika ada yang menghina idola kpop yang disukai, subjek EW akan mengabaikan orang tersebut, karena bagi subjek orang tersebut tidak sebanding dengan idola k-pop yang disukai. Subjek EW tidak bisa berhenti setelah menyukai kpop, bagi subjek menyukai k-pop merupakan kesenangan bagi dirinya dan tidak berdosa jika menyukainya.

Subjek SP akan merasa sedih jika tidak mengetahui tentang idola yang disukai, subjek merasa sedih jika mendengar berita idola yang disukai akan melakukan wajib militer dan sebaliknya subjek akan merasa senang jika idola yang disukai berkarya kembali dan subjek akan merasa marah, menyerang balik, dan membela idola yang disukai saat ada yang menghinannya.

Ketiga subjek sadar bahwa idola k-pop yang disukai mempunyai pengaruh ke kehidupan subjek, sesuai dengan pendapat Baihaqi (2016) mengatakan kesadaran adalah kesiagaan individu terhadap stimulus-stimulus lingkungannya serta peristiwa-peristiwa kognitif berupa afeksi, pikiran, dan respon-respon terhadap stimulus fisik.

Ketiga subjek menunjukkan perilaku Celebrity Worship yaitu terlihat ketiga subjek menampilkan bentuk-bentuk kecintaan subjek terhadap idola k-pop yang disukai, obsesi kecintaan terhadap idola kpop yang disukai, serta pemujaan berlebihan yang dilakukan subjek terhadap idola k-pop yang disukai. Perilaku celebrity worship dapat menjauhkan dari ajaran islam karena terlalu mengidolakan selebriti. Sebagaimana Firman Allah dalam QS. Ali -Imran 3:28:

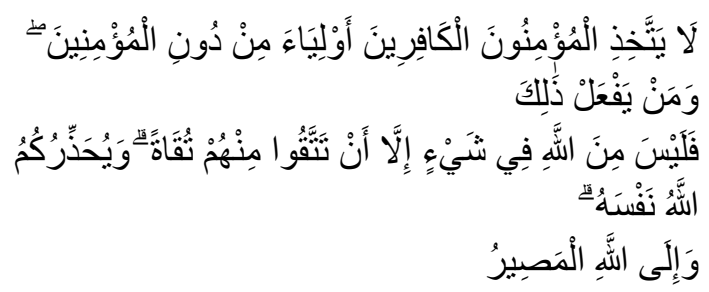

Artinya :"Janganlah orang-orang mukmin mengambil orang-orang kafir menjadi wali dengan meninggalkan orang-orang mukmin. Barang siapa berbuat demikian, niscaya lepaslah ia dari pertolongan Allah, kecuali karena (siasat) memelihara diri dari sesuatu yang ditakuti dari mereka. Dan Allah memperingatkan kamu terhadap diri (siksa)-Nya. Dan hanya kepada Allah kembali(mu)". (QS. Ali-Imran 3:28)

\section{Kesimpulan}

Berdasarkan hasil temuan penelitian dan pembahasan mengenai Celebrity Worship pada Dewasa Awal Penggemar K-Pop di Palembang bahwa gambaran Celebrity Worship ketiga subjek yaitu ketiga subjek menampilkan perilaku obsesi kecintaan terhadap idola k-pop yang disukai dan pemujaan irasional terhadap idola k-pop yang disukai. Ketiga subjek merupakan 
penggemar k-pop dewasa awal di Palembang yang melakukan Celebrity Worship, menunjukkan perilaku Celebrity Worship dari ketiga subjek menampilkan bentuk-bentuk kecintaan subjek terhadap idola k-pop yang disukai, obsesi kecintaan terhadap idola k-pop yang disukai, serta pemujaan irasional yang dilakukan subjek terhadap idola k-pop yang disukai.

Faktor-faktor yang mempengaruhi ketiga subjek berdasarkan tema tiga alasan dari dalam diri dan tema empat alasan dari luar diri subjek melakukan Celebrity Worship yaitu faktor dari dalam diri dan faktor dari luar diri. Faktor dari dalam diri subjek yang mempengaruhi ketiga subjek karena ketika subjek mempunyai ketertarikan dari dalam diri terhadap idola k-pop yang disukai, ketertarikan terhadap penampilan fisik, kemampuan, serta sikap-sikap idola k-pop yang disukai. Faktor ekternal untuk subjek tiga karena adanya pergaulan dari temanteman subjek dan didukung oleh perkembangan teknologi, sedangkan untuk subjek satu dan dua karena adanya lingkungan keluarga, teman dan perkembangan teknologi. Perkembangan teknologi sangat mempengaruhi ketiga subjek melakukan pemujaan terhadap selebriti terlihat dari tontonan televisi, sosial media seperti youtube, instagram, facebook, dan twitter. Serta jaringan internet yang sangat berkembang pada saat ini.

Adapun saran yang ditujukan oleh peneliti dari hasil penelitian ini adalah sebagai berikut:

1. Bagi Subjek

Diharapkan bagi subjek mampu mengurangi intens waktu yang digunakan untuk mengetahui idola, memampaatkan sosial media dan waktu luang untuk aktivitas yang lebih bermanfaat untuk kesehatan baik secara fisik maupun mental.

2. Bagi Keluarga

Diharapkan bagi keluarga subjek mampu mengontrol dan mengawasi perilaku subjek pada saat melakukan aktivitas-aktivitas yang dilakukan subjek.

3. Peneliti Selanjutnya

Diharapkan bagi peneliti selanjutnya mencoba meneliti tentang Celebrity Worship dengan menggunakan metode penelitian yang berbeda, serta dapat melengkapi kekurangan yang ada.

\section{Referensi}

Afrisia, R.S. (2019, 10 Januari). Penggemar Hallyu di Dunia Hampir Tembus 90 Juta Orang. Cnindonesia [on-line]. Diakses pada tanggal 7 Maret 2020 dari

https://www.cnnindonesia.com/hib uran/20190110173339-241359969/penggemar-hallyu-didunia-hampir-tembus-90-jutaorang.

Alwisol

(2009).

PSIKOLOGI KEPRIBADIAN. Malang: UUMPRESS.

Angeline, N. (2019, 20 Januari). Dicap Alay hingga Jadi Tren, Begini Perkembangan K-Pop dari Masa ke Masa. detikHot [on-line]. Di akses pada tanggal 17 Februari 2020 dari https://hot.detik.com/kpop/d4392910/dicap-alay-hingga-jaditren-begini-perkembangan-k-popdari-masa-ke-masa

Anggraini, S.D. (2018, 30 Agustus). UKLI (United Kpop Lovers Indonesia) Komunitasnya Pecinta Korea di Palembang. Tribun Sumsel [online]. Diakses pada tanggal 17 Februari 2020 dari https://sumsel.tribunnews.com/201 8/08/30/ukliunited-kpop-lovers- 
indonesia-komunitasnya-

pecintakorea-di-palembang.

Azwar, S. (2016). Metode Penelitian. Yogyakarta:

PUSTAKA PELAJAR.

Baihaqi, M. (2016). Pengantar Psikologi Kognitif. Bandung: PT Refika Aditama.

Darfiyanti, D., \& Putra A., B-M.G. (2012). Pemujaan terhadap Idola Pop sebagai Dasar Intimate Relationship pada Dewasa Awal: sebuah Studi Kasus. Jurnal Psikologi Kepribadian dan Sosial Vol. 1 No. 02, Juni 2012.

Dayaksini, T., \& Hudaniah. (2015). Psikologi Sosial. Malang: UUMPRESS.

Frederika. A., Suprapto, M. H., Tanojo, K. L. (2015). Hubungan antara harga diri dan konformitas dengan celebrity worship pada remaja di Surabaya. Jurnal Gema Aktualita. 4(1), 61-69.

Herdiansyah, H. (2015). Metodelogi Penelitian Kualitatif Untuk Ilmu Psikologi. Jakarta: Salemba Humanika.

Hurlock, E. B. (1986). Psikologi Perkembang suatu rentang kehidupan. Jakarta. Erlangga.

Maltby, J., Day, L., McCutcheon, L. E., Houran, J., \& Ashe, D. (2006). Extreme celebrity worship, fantasy proneness and dissociation: Developing the measurement and understanding of celebrity worship within a clinical personality context. Personality and Individual Differences, 40(2), 273-283.

Maltby, J., HARI., \& Liza. (2011). Celebrity worship and incidence of elective cosmetic surgery: evidence of a link among young adults. Journal of Adolescent Health, 49 (5), 483-489.

McCutcheon, L. E., Ashe, D. D., Houran, J., \& Maltby, J. (2003). A cognitive profile of individuals who tend to worship celebrities. The Journal of Psychology, 137, 309-322.

McCutcheon, L. E., Ashe, D. D., Houran, J., \& Maltby, J. (2004). Celebrity Worshipper: Inside the Minds of Stragazers. Amerika: PublishAmerica

Monks, FJ. (2006). Psikologi Perkembangan. Yogyakarta: Gajah Mada University Press.

Papalia, Old, \& Feldman. (2008). Psikologi Perkembangan. Jakarta: Kencana.

Penjualan Album K-pop Meroket di Masa Pandemi Covid-19 CNN Indonesia. (2020, 24 November). Cnindonesia [on-line]. Diakses pada tanggal 11 April 2021 dari https://www.cnnindonesia.com/hib uran/20201124134023-227-

573801/penjualan-album-k-popmeroket-di-masa-pandemi-covid19

Pradoko, S. (2017). Paradigma Metode Penelitian Kualitatif: keilmuan seni, humaniora dan budaya. Yogyakarta: UNY PRESS.

Putri, L.M. (2020, 11 Maret). 21 Istilah Terbaru K-Pop yang Pemula Wajib Tahu, Mulai Dari Roti Sobek Sampai Blasteran Surga-Korea. Kapanlagi [on-line]. Diakses pada tanggal 20 Februari 2020 dari https://www.kapanlagi.com/korea/ 21-istilah-terbaru-k-pop-yangpemula-wajib-tahu-mulai-dari-rotisobek-sampai-blasteran-surgakorea-c11989.html.

Raco. (2010). Metode Penelitian Kualitatif Jenis, Karakteristik, dan Keunggulannya. Jakarta: PT Grasindo.

Santrock, J-w. (2018). Life -span development (perkembangan masahidup edisi ketigabelas jilid 2). Jakarta: Erlangga.

Sugiyono. (2016). Metode Penelitian Kuantitatif, kualitatif dan $R \& D$. Bandung: Alfabeta.

Sunarsi. 2016. The Impact Of Celebrity Worship On High School 
Adolecent's Self Identity In Yogyakarta. E- Journal Bimbingan dan Konseling. Edisi 1 Tahun ke-5. 